\title{
Beyond Art, History and Social Discourse: A Study of Folk Art as Indigenous Knowledge System in the Grass Field of Cameroon
}

\author{
Donatus Fai Tangem \\ University of Yaounde1, Cameron
}

*Corresponding Author: Donatus Fai Tangem, University of Yaounde1, Cameron

\begin{abstract}
The emergent prominence of folk and popular culture as subjects of intense debate among scholars is, to say the least, a ratification of the tremendous power of knowledge and value of African indigenous civilization. The launch-pad of this research is the crucial potentialities perceptible both in folk music as well as sculptures of African origin. That folk art as a whole constitutes a reservoir of the quintessence of societal motif, value and a moral code, is too evident. Additionally, this art also projects the creative forte that underpin indigenous knowledge generation systems. This is to say African indigenous civilization reserves inbuilt mechanisms for knowledge generation and transfer without recourse to western approaches. With apologies to no one, folk arts generally command respectability and acknowledgement hitherto denied by conservative scholars. In Africa, folk music like sculptures, underscore expressive forms of knowledge on a wide variety of issues of both individual and collective concern. In Cameroon, the folk musician uses his art variously to describe, comment or simply recount issues and events important either to himself or to the community. In essence, his role goes beyond entertainment and is almost invariably steeped within untainted indigenous perception. Considering the need to evoke the hidden power of folk art, this research will sought answers to such questions as: What are the specificities of folk music and sculptures? How does folk culture represent collective memory and experience? What aspects of historiography and resource material is discernible in folk arts? These questions constitute the framework of an endeavor meant to complement existing research by flushing out the empowering content of African folk music and the educative aura of her sculptures. Through field work and interviews with curators, palace attendants, folk artists and fons/notables from selected Grassfield palaces, this research constitute a lobby force for a policy formulation in respect of the need to preserve and protect ancient folk arts and artifacts, these being enviable sign posts of indigenous African civilization. The analysis is predicated against the theoretical paradigm of Social Semiotics by Theo van Leeuwen on the one hand and Robert Hodge and Gunther kress on the other.
\end{abstract}

Keywords: Folk Art, Social Discourse, and Indigenous Knowledge Systems

\section{GENERAL InTRODUCTION}

The power of African civilization is definitely measurable in terms of how and what its inbuilt mechanisms represent and transmit. In the preface of his study (Leeuwen T Van; 2005) observes that:

Just as in linguistics, the focus changed from the 'sentence' to the 'text' and its 'context', and from 'grammar' to 'discourse', so in social semiotics the focus changed from the 'sign' to the way people use semiotic 'resources' both to produce communicative artifacts and events and to interpret them - which is also form of semiotic production - in the context of specific social situations and practices. (v)

Prominent tools and vehicles of communication through the employment of signs, sounds and symbols include folk music on the one hand and sculpture on the other. Even though the relevance of these tools as vehicles of knowledge generation and transmission is incontestable, some Western scholars have turned to downgrade African folk culture describing it as primitive and mean. This underestimation is due essentially to its complex and complicating protocol and its numerous ritualistic bases. Yet beyond these, African folk art is applied art created in the service of the society and for the wellbeing of the people and the community at large. Paul Jenkins makes the point even better when he argues in (Knopfli, 2002) that:

Rather than imposing a preconceived order on themselves. Grass Landers in this field of intellectual effort are seeking to understand and to influence events which impinge upon 
their lives - to generalise - what the gift of observation is telling them. They are open to new suggestions about what things happen and they develop new interpretations themselves (p. 14).

It is therefore, easy to discern the presence of traditional beliefs and practices in material culture.

The area that is commonly referred to as the Grassland in Cameroon is geographically the land area that spans across the Northwest and Western Regions with headquarters in Bamenda and Bafoussam, respectively. This area is adorned with rolling hills, waterfalls and vast savannah plains that distinguish the area from the tropical rainforests of the Southwest and other parts of the country. Although the Northwest and Southwest are the two English-speaking regions of the country, they hardly share any serious traditional and customary practices. Instead, the Northwest shares very close cultural and traditional ties with the Western Region. Therefore, certain artefacts, traditional beliefs and practices cut across the Grasslands such that indigenes have no difficulty understanding and interpreting the codes and iconographic motifs on arts and crafts from any of the two regions. It is important to note that according to the hierarchy and traditional setting of the Grassfield, the palace is the centre of all social, cultural and political activity of the Fondom. The term Fondom describes the traditional area of jurisdiction over which the Fon, as traditional authority has and does exercise power. Palaces are therefore important traditional stations and socio-political and cultural headquarters of all activities in the land. This means that Grassland palaces are the first port of call by visitors and strangers irrespective of the raison d'être of their mission. Also, palaces are set up and manned by various departments such as council of elders and secret societies designed for specialised and initiated members of the community. Within the palaces are specialised committees that correspond to the modern day ministries and departments such as Law and Order and Justice and Peace. In Nkambe Fondom for example, the various secret societies in existence include, the Samba, the Nfuh and the Nwerong. Ideally, every fondom is made of family and family-heads, quarter, and quarter-heads. Sub-chiefs have power over quarter-heads but are in turn subservient to the Fon. On his part, the Fon is answerable to Nwerong and the seven pillars of the land. According to Ta Shey Ngah of Mbot village, in Donga Mantung, the Fon rules in accordance with the views of Nwerong and the king makers. Architecturally, the Grassland palaces are designed and uniquely constructed in every Fondom such that it is easy to identify a palace in the Grassfield. For effective operations,. strangers and visitors are expected upon arrival in every Fondom or Kingdom to stop first at the palace. Therefore the decor and ground plan of Grassland palaces are often adorned with special artefacts, sculptures and or paintings that carry profound meanings and sometimes serve as instructions to visitors. This explains why the court art on display at prominent positions around the palace call for special attention beyond their aesthetic consideration.

In the opening pages of his other publication, (Knopfli; 1997:2) stipulates that "The Traditional worldview and fundamental beliefs of the Grasslands are manifest in the court art which links different generations in an ongoing pattern. Thus, it represents a kind of collective memory". It can be said that contemporary liberal minded scholars have begun to review and even question earlier conservative perceptions about African folk art. There is yet residual misconceptions that looms and which have damaging effects on the indigenous motivation of its creation. The enthusiastic admiration of folk art and the need for preservation is ocular evidence of the discovery of its concealed values. No doubt (Hodge and Kress; 1988) intimate that "Semiotics offers the promise of a systematic, comprehensive and coherent study of communication phenomenon as a whole, not just instances of it" (p1),

In an interview with a prominent sculpture, Toh Robert Mbenchu of Babanki Tungoh, the 85 year old folk artist and carver noted that the ultimate motivation that underlie his passion for carving, is the wish to be serviceable to the community. He adds that as much as this domain of trade offers him some financial rewards, his ultimate satisfaction and sense of fulfilment is in the contributions he makes to the community as a whole and at the service of his culture and tradition. These views tie neatly with (Bogart: 2007) who argues that:

If the motivation for action does not transcend the desire for fame and success, the quality of the results will be inferior. If your aim is intense engagement rather than selfaggrandisement, the result will be richer, denser and more energetic. The outcome of an artistic process contains the energy of (his) commitment (p.6). 
What this implies is that the raison d'être of every endeavour must transcend superficial objectives. This is also a way to advocate for services that target superior objectives rather than purely personal fulfilment. The superior objective of the production of folk art was more for what it meant and achieved for the community than for what it did to the artist. Because folk artist focused not their eyes on the material benefits of their products, but on how serviceable their products were to the community. The relevance and value of such art works to the community could not be dissociated from the moral questions and the educative intentions behind them. Once again Anne Bogart's classic recipe turns handy in the advocacy when she identifies the threefold principle:

\section{- You need something to say \\ - You need technique; and \\ - $\quad$ You need passion.(8)}

The urgent need to rectify certain misconceptions about the need to preserve and protect folk art is therefore unarguable. Among this is the persistent conception that folk art as a whole promises instant bailout from issues of unemployment owing to its economic potentials for material prosperity. While this ideological standpoint is a derivational truism, it remains a simplistic and "egocentric" validation of a product - not for what the product stands for and can do for a people, but for what its author stands to benefit. The underlying sacrilege in this proposition is the resulting banality with which the art will be associated once hungry and money thirsty young people take to it. It is therefore possible that Eurocentric perceptions and appreciation of African folk art omitted and continues to omit the sacred religious dimension of what it stands for. The point to stress here is that the power of folk music and the value of sculptures are better measured against the hidden strengths of African civilisation that they incarnate. This is obviously not so for a visitor enthused by the grandiose appearances and spectacular display of artefacts and relics that they see around the palaces. Their attraction is basically for their aesthetic accomplishment. Paradoxically, the indigenous folk artist does not consider his service and end product merely as "Art". Rather, they consider their engagement, passion and committed work approach as an obligation they owe to their ancestors and to the environment in which they live.

In Cameroon, like in other African countries, traditional crafts and art works that cause immeasurable attention owing to their attractiveness include weaving, stitching of traditional dress, carving, pottery, smelting and smiting. To this must be added song, dance and folk music that are also used for the generation, interpretation and transmission of information as well as the expression of individual or collective issues of concern. For the most part, popular acclamation of indigenous art by tourists and some researchers has turned to be limited to their "material" function which does not bring out their full meanings. As already indicated, folk art has an unmistakeable economic potential, but its original intrinsic spiritual and cultural or religious values have not been appropriately appreciated. When (Hodge and Kress; 1988) argue that " signs may not be divorced from the concrete forms of social intercourse seeing that the sign is part of organized social intercourse and cannot exist as such outside it" p18. It follows that the motivation for the creation of what has increasingly been described as art was the search for a means by which to impact the community as a whole or meet a particular challenge thereby justifying its creation. It was thus common expectation that after transiting childhood and adolescence, one was expected to prove his manhood or womanhood by being productive and of some service for the family, self or entire community. It stands to reason that the motivation for example, to manufacture a "kotokorh", or wooden bicycle or "rpih" bamboo car, were respectively to speed-up transportation and movement of a person from one point to the other and to convey farm products from the bush, than for poverty alleviation.

Similarly, carvers like basket weavers and dress makers, set out to render services to the communities and families than to solve economic problems of poverty and unemployment in their contemporary usages. Therefore wine tappers, like hunters and fishermen were hailed just like carvers, weavers and Black-smites. The difference is that while basket weavers like metal smelters satisfied and met tangible objectives, carvers like singers and dancers played great spiritual, religious and cultural functions that have remained incomprehensible to passive observers. That folk art goes beyond the aesthetic perception is the way by which to underscore the intrinsic values of sculptures and indigenous music as products of African civilisation which more than equal Western techniques and accessories of knowledge generation and communication systems. 
For a long time the glaring reality of African art-forms as reservoirs of knowledge and systems of communication have either been ignored or undermined. Whether or not this phenomenon has been accidental or by design is immaterial. What remains clear is that the consequence of such a dangerous situation is not difficult to understand. A review of existing literature written on the subject and related areas, reveal that some authors of such publications omitted aspects that conflicted with their faith and overall mission of their sojourn in Cameroon. For example, the sizeable publications by (Kropfli 1997) attempt to capture a part of the spiritual, religious dimensions of the arts and artefacts. According to the Swiss Basel Mission evangelist, the Art and Craft of the Grassfield is a recapitulation of their perception that needs to be preserved owing to its economic potentials. This point is buttressed by his colleague and fellow pastor, Aaron $\mathrm{Su}$, who in the preface declares:

It is my ardent hope that the youth of Cameroon will regain interest in manual work, reawaken their enthusiasm for traditional art and craft, and not depend solely on imported goods.... They should be patriotic enough to maintain positive aspects of traditional culture. Local production is a sure way of developing and expanding our national economy (p. VI)

A much closer and semiotic appreciation of the arts and artefacts of the Grassfield of Cameroon show them as profound communication codes demanding grounded interpretation for proper understanding. Thus folk music from the western region is perceived to be embedded with deep and significant codes while sculptures from the north western region also carry profound symbols that require deep analyses for the evocation of their real values and incontestable significance to the people and their culture. However, in both artistic expressive forms, indigenous knowledge systems are evaluated against the backgrounds of values and issues embodied in them and for which the people hold to be sacrosanct.

\section{FolK MusiC AND Indigenous KNOWLEDGe System}

The increasing popularity of popular culture as an avenue for the articulation of societal concerns has already been established. However, the special power of folk music at the service of history and socio-political issues needs to be highlighted. The Bamuns in the Western Region of the Grassfield area of Cameroon take particular interest in folk music which they produce and use for certain societal objectives. Besides all else, folk music in Bamun is employed as an avenue of dialogue, public discourse and general expression of either individual or collective viewpoint. For this reason, a royal orchestra is set up at the palace and is equipped with diverse traditional musical instruments. These instruments are manipulated variously to obtain remarkable sound results that combine with the lyrics sung. Needless to emphasise that musical instrument speak and are clearly understood by community members. In exploring the language of the drum (Knopfli 2002) explains:

A message is sent out by playing the drum. The drummers in the next village listen to the message and pass it on to the third village while they are drumming the drummers in the first village listen very carefully; examining the second drumming of the message to make sure there has been no grave misunderstanding of what they were transmitting. If something has been understood wrongly, the correction is drummed immediately thus ensuring that no error be passed on to other villages. In this way a message travels far and quick, (P.38).

The Fon of Nkambe holds that the language of musical instruments sometimes communicate better and clearer, especially within the context of wars. In an interview Mpouapon Yaya, prince and head of the royal orchestra, holds that different sounds produced within a musical display is often in tandem with the content and objective of the particular music. In the same interview Yaya reveals that in Bamun land, music is considered as proper medium of information and general sensitisation on important issues concerning the society. This explain why, as he says, folk music is not a child's play and often goes beyond entertainment. In discussing the special place that folk music occupies in the traditional outfits of the people, he emphasises that different hierarchical class and social status of the Bamuns have different songs, dances and music that distinguish one from the other. In respect of cultural prescriptions, princes have their music, song and dance that have distinct features from the music of the notables and the commoners. Each of these classes has specific sounds that they use as insignia and identifying symbols. Even so they are allowed to produce certain sounds only when the said musical display is attended by the Sultan who is the traditional authority of all Bamuns. It follows that the music of the Sultan is distinguishable by the numerous sounds of animals that are associated with royalty. It is possible to decipher the different classes of music by both the content of lyrics as 
well as by the sounds produced. During festivals, notables, princes and commoners all take turns in singing and display that may or may not require instant response from the king. However, when necessary, the king rises amid ululation and representative royal sounds to respond to the issues as the case may be. A case in point is reported by (Lantum 1994) when he recounts the experience during a festival where sultan Njoya attended:

The sultan was carrying the $15 \mathrm{~kg}$ gong in his left arm with the rope suspended over his shoulders and playing it with the stick in his right hand. Occasionally he paused to receive applause from yelling crowds standing along the roadside and to play with them: gong! gong! gong!At intervals he led the chanting by intonin; Lum Nyam! O lum nyam! And we responded in the same chorus (P.10)

In sum, the content of music and song range from petitions, reports, interrogation and sometimes critical evaluation of the socio-political preoccupations. This means the traditional setting of the Bamuns makes provisions for all and sundry to actively partake in the governance and conduct of local community affairs. This democratic posture is further buttressed by the existence of the different secret societies and regulatory bodies whose roles are clearly spelt out in unwritten but well understood traditional portfolios. Through the sound of music, questions are posed and answered. There is allowance for a follow up that may be made through a solo singer against the backdrop of a chorus. Therefore discussions, debates and outright instructions can all be handled through music, song and dance. Besides the sounds produced, the paraphernalia and display of the musician adds value to the content of the discourse and the subject under review. This is particularly true of what Yaya in the interview refers to as "healing music" which is the reserve of the initiated. That music is also used for the treatment of patients suffering spiritual attacks and mystical manifestations, is to say music to the Bamun is more than the clanging of instruments and show. The different musical instruments used by folk musicians include the xylophones, skin-covered drum, the slit drum, the basket hand rattle, calabash rattles, single and forked fruit-shell rattles, foot, ankle or calf rattles and the sanga (ndenge). Wind instruments (aerophones) include Flutes, hand trumpets, the ivory trumpet and the harp, also known as "mvet". These instruments each have and do play specific functions in the composition of music.

When receiving visitors and strangers, music at the royal palace is used as a pretext for speeches and cultural exposition. It is also believed among the Bamuns that playing certain musical "notes" and sounds to the visitors is a way to probe into the psyche, "hypnotise" and may sway a visitor from any evil plans. Otherwise, music is also used to understand the object of a visit. The multiple implications are therefore that, the folk musician is a chronicler, a story-teller, a praise singer, social commentator, political adviser and cultural activist among others. While he may get paid for "amusing" his audience, the folk musician does not shy away from a nasty truth, not even when it has the force of hurting listeners, be there visitors or indigenes. In his opinion Abdou, a community radio animator argues as follows:

In Foumban traditional setting, the folk musician is an impartial social servant. His art is inspired by the socio-political and economic condition. But he does not fake or imagine any scenario. His music is often based on practical life experience about which he has a strong urge. His experience pre-disposes him to better understand and advice the local traditional authorities on the real happenings in the land. He is thus consulted on certain matters and decisions which are brought to the attention of the public through the agency of his art (personal Interview, 2014).

The role of the folk musician in the Bamun land is likened to that of a human right activist as well as justice and peace advocate. Because he strives to be as impartial as it is necessary, some folk artists are considered as conscience of society. Yaya (2014) continues to argue that because of the influential role of the folk artist in Bamun, the choice of the official artist to animate the royal orchestra is not done haphazardly. Serious background check is sometimes orchestrated by the traditional council or advisers. A wayward person may not be recruited even if his artistry as a singer is well established. To be endorsed as palace artist, one needs to be talented, but also to be of untainted moral probity. Risking a liar and manipulator as a trusted servant of the Bamun people is to risk destruction of the culture and cherished values of the community. Accordingly Bamoun people think money is good, 
very good, but must not be seen to be the major motivation behind a folk performer's job when called up. He likens this to the phenomenon of charlatans cum journalist whose job can disorientate a community leading to faulty panic with possible life threatening outcomes.

It is also important to note that in the Bamun land, palace court artists are classified variously. There are essentially praise poets and amusement folk artists whose job it is to extort the virtues of love, beauty and honesty. These categories of folk performers are often invited to ceremonies of different types - birth, marriages, baptism, or death and commemorative events. The category of folk performers that animate social events share one common feature - their art and artistic display is often motivated by the prevailing atmosphere and sometimes their outright mendicant postures speak to their level of social standing. On the other hand, recognized and appointed member of the royal orchestra performs his art with dignity while focusing on a more superior objective of rendering service to the community without expecting any material or financial fallout. This class of folk artist does not have their music on commercial desks in the market. Rather, royal musical collections are donated to visitors as souvenir from the short or long stay in and around the Bamun land.

In an attempt to probe into the origin and development of Bamun folk music, Abdou recounts that Sultan Njoya founded, and arranged certain musical genres for specific purposes. Prominent among these is the popular "Mundu" music which is played and enjoyed all over the Bamun kingdom. Because of its wide appeal, "Mundu" is often a mixture of education, sensitisation and entertainment. The lead singer often tunes his discourse to suit the prevailing circumstance. An example of "Mundu" that is laced with social satire is one played by Aladji Mambi that focuses on a matrimonial quarrel. The substance of the lyrics is the ordeal of a woman who after years of committed struggles to assist her husband out of poverty and misery, the man drops and jilts her once he becomes wealthy and popular. The lamenting woman reminds the man of his miserable days imploring him to honour the conjugal pledge which they both shared a few years back. In her misery, she appeals to the man:

Oh my husband

Dear, husband

When we first met we loved

When we first met we professed love.

In your misery, terrible misery, you professed love.

In your misery, terrible misery professed love.

In our collective misery, there was love.

It is love that held us together in spite of the odds.

I am a worthless woman

Even though I supported you,

I am a useless woman.

Dear husband, my natural

Inability to conceive is cause for

My damnation

Oh, Dear husband, your support

System is now worthless.

After helping to lift you out

Of poverty and misery

I am now worthless. 
Beyond Art, History and Social Discourse: A Study of Folk Art as Indigenous Knowledge System in the Grass Field of Cameroon

Oh, worthless, but useful only in your time of need.

Oh, worthless, but useful in

Moments of misery

Oh, oh, oh -

The world and its people.

The foregoing effectively recapitulates the social services as well as the duty that folk musician owes and do play for the community. This brand of music with its social appeal and rhythm is characteristically different from the "Mbansie" folk music that is the reserved of princes, princesses and their descendants. This folk dance, both Abdou and Yaya (2014) underscore, is uniting and generally played when there is need for the king and his immediate descendants to rally for an important family issue. Within the context of dance and music, important matters are raised and discussed thereby setting a base for resolution. Interestingly, this dance is not open to non-members of the immediate royal families.

Similarly, "Kna" music is the preserve of initiated secret society members. Some regulatory bodies and cult groups are known as secret society because as (Kropfli 1997), specifies they conceal their rites and activities from those who are not members though results are sometimes made available to the public. During such moments, the griot, another very important community folk performer takes it upon himself to provide transitional music and play for time. It is generally held that griots sometimes are used by the different arms of traditional administration to test or sample public opinion on a burning socio-political or economic issues. According to Abdou (2014) grios are often employed as the mouthpiece of the king. They interpose their services in situations of conflict and social discord. Tense situations and occasions of lid-flipping anger are real test of grio's art as he is often expected to re-establish peace and facilitate dialogue and reconciliation. At such moments, griots replay and recount in music the causes and course of disputes thereby inviting the parties concerned to show restrain, respect and act in the dignity that befits real sons or daughters of the Bamun. He adds that there are very rare situations in which the intervention of griots through their music and display, failed to restore peace and initiate reconciliation.

In Bamun kingdom, music, song and dance, are also used as indicators or markers of their invincible fighting spirits. For example, it is widely held among the Bamuns that "Kpalum" is captive music that was appropriated from the Palum people who were overpowered by Sultan Njoya during the wars of expansion. The principal musical instrument of "Kpalum" is the Kpekpet - which is also known in Limbum as Kwakwar. "Kpekpet" is made from a dry piece of bamboo into which deep cuts and dents are made. It produces a kind of coarse crocking sound when any iron, metal or hard object is scratched along the furrows of the deep cuts. The instrument is also used to produce frog like sounds when need be. It is important to note that Kpalum did not originally use the Kpekpet as a major instrument; it was introduced after the music became appropriated heritage of Foumban following the capture of the Palum. On its part "Ngiri" music is also a product of another secret society but it is not wholly restrictive. Non-members are allowed to participate in the music but cannot be lead singers or frontline animators. On special occasions however, initiated "Ngiri" members may be allowed to initiate warriors in the face of an impending warfare. During this time a war dance, known as "Njampit" is executed to galvanise and energise the warriors preparing them for battle.

In conclusion it is ideal to restate the forceful argument by (Knopfli 2002) that;

Music and dance have both social and religious functions in the Western Grasslands. The dancer becomes part of the great cosmic power which gives life to all things. Dance is a ritual. It is an expression of the life force which is inherent in us all. I would argue, as a pastor and a missionary that dance has always been the most expressive form of prayer in the African communities of the Western Grasslands. Indeed, music and dance give expression to the people's faith in and concept of God. In their traditional religion, music and dance embrace all aspects of social life and can give an outsider vital insights into a people's contemporary religious world-view (p.26-27). 
Beyond Art, History and Social Discourse: A Study of Folk Art as Indigenous Knowledge System in the Grass Field of Cameroon

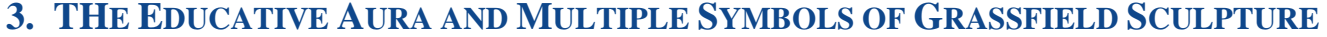

The preliterate power and appreciative value of Grassfield sculpture surpasses by far their aesthetic attraction. Behind or beyond their tangible and physical appearances are profound intangible issues that are of far greater significance than the concrete physical object. This is exactly how and why Grassfield sculpture demands a little more than enthusiastic admiration of its physical concrete appearance. To transcend the physical, it is important to understand the symbols which are employed to communicate both common and uncommon truths and abstract ideas about life and its meaning. To locate such very highly symbolic properties of African civilization in and around the palaces and religious as well as cultural places, is an indication of the value the people associate with those places. As already indicated, palaces in traditional Grassfield setting are the centres of socio-cultural and political life of every community. Therefore to reach out to strangers and offer quick lessons, instructions or code of conduct to visitors, court art and sculptures do the trick. The gallery display of arts, artefacts and sculptured items constitute ocular evidence of transparent, informative and democratic culture of traditional Africa.

Many informants such as museum curators, sculptors, palace attendants in Bali, Mankon, Mbot and Kungi, are unanimous that the gallery display in palaces are a warning or better still an invitation to watch one's ways and action. To a very large extent, one can rightly refer to the sculptures and artefacts as traditional book collection that ought to be quickly perused free of charge by visitors and researchers. It is also right to claim that what is seen on display is only a cover of the book and so any interested and curious visitor, must then ask questions about what he sees and what he does not understand about them. That is how to open the book and read. Reading the "open books" displayed around palaces is analogous to interpreting the complex iconographic symbols engraved on carved items. The prominence of the different iconographies is noticeably used on a wide array of prestige items as well as architectural décor, household properties and utensils. To better understand the symbols on display in the Grassfield, it is worth reaffirming (Kropfli 1998) that:

In most of the ethnic groups of the Western Grass Lands the craft of wood carving has been developed to a remarkable high standard. The powerful and steadfast personalities of the Fons, Chiefs and Sub-Chiefs, Quarter-heads, Noblemen, and other dignitaries, who form the traditional elite and leadership of these ethnic groups, held this fine art in high esteem, and also greatly influenced it (p.13).

It is no doubts therefore that the art is created at the service of the Fon and his elite. As such it is used to strengthen the respect and admiration considered appropriate to them and their supporters. This is to say arts recapitulates and represents the dreams, hopes, and fears of the people thereby contributing directly to their welfare. In general terms, the symbols found on artefacts and carved objects are basic indicators of a people's way of life and overall perception of their social, the spiritual and the material properties at their disposal. In essence Grassfielders use the practical realistic (flora and fauna), environmental wealth which they condition to serve their culture, religion and social and economic systems. To a Grassfield person, there is practically no aspect of the natural environment that is not appropriated to serve either the material or spiritual need. Ranging from birds, animals, and aquatic life, the Grassland is reputable for harnessing natural environmental gifts of flowers, fruits, trees and leaves for their general welfare. Since the art, as has been established revolves around the traditional authority as well as royal lineage, it is ideal to underscore the relationship between birds, animals and the trees and flowers with the authority of the king. In establishing the crucial relationships between the environment and kingship authority, (Ngitir 2013) opines that:

The icons and the luxury materials (beads, cowry shells, brass (bronze, and ivory used as icons) have become symbolic of the values and beliefs embedded in society \& politically stratified cultural systems (--). It comprises human representations and some principal zoomorphic symbols such as the leopard, the elephant, the buffalo, the python, the crocodile, the lizard, the chameleon, the frog or toad, the spider and the bird (P 173).

The symbolic representation of these is more prominent on carved objects that every community uses for either daily or occasional affairs of general, personal or collective concern. Traditionally, most Grassfield royal authorities are symbolically represented by different species of animals. These animals have eventually been adapted as insignias of cultural and spiritual powers and where 
appropriate, different animals are looked upon as totemic incarnations. Thus their body parts, coat, teeth, horns, etc are used to reinforce the extra-super natural powers with which the king is associated. The reason for the inextricable connection between royal authority and the ferocious and awe inspiring animals is very simple. They are used as deterrents to enemies or any potential assailant contemplating warfare. Generally, the entrances into palace yards and galleries are usually adorned with royal animal motifs that immediately spell out in unmistakeable signs, the particular animals with which the particular royal authority is associated. At the gateway into the Bali-Nyonga palace is an artistic display of the different images of the animals and elephant tusks which all combine to establish the multiple prowess and magnificence of the royal authority of Fon Galega II.

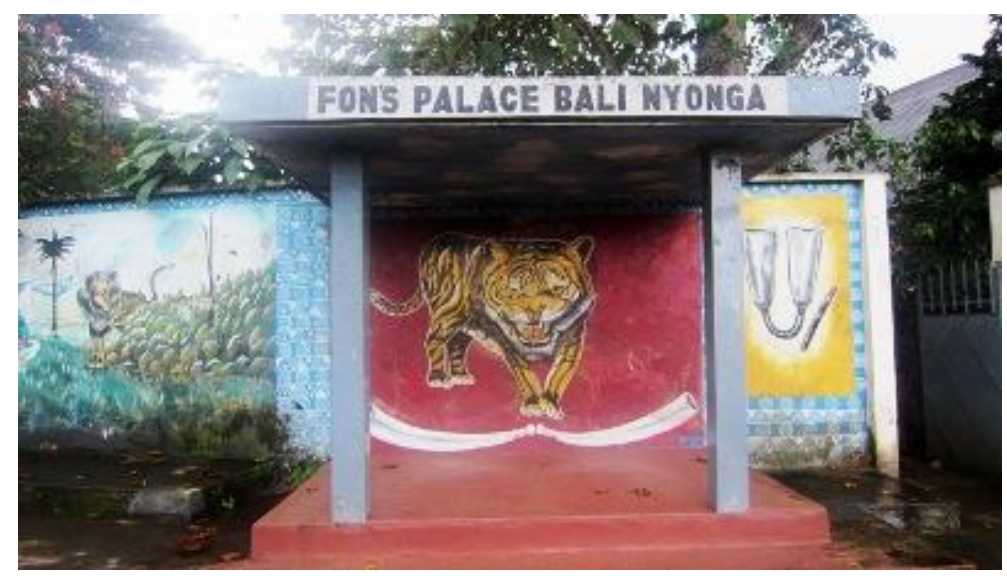

Bali Palace August 2014

Source: (Donatus Fai Tangem2014)

Similar zoomorphic and anthropomorphic motifs and sculptured animals such as the lion, tiger and the buffalo garland the Mankon palace courts. However, in some palaces like that of Mbot, and Kungi, these iconic representations are reduced to the minimum from the outside view. The décor within these palaces manifest equal grandeur as the external décor in Bali-Nyonga and Mankon. Generally, some wealthy palaces like that of Santa display with appreciable generosity a cross section of most of the animals associated with royalty. In an admirable pictorial arrangement, the expensive bronze designs of animals and associated royal symbols speak to the diverse perceptive power with which the Fon, traditional leader of all Santa is associated. In this case the gallery display is both ocular show of economic and financial power as well as impressive indicators of the complex variety of totems that such royalty is likely to command. In yet other settings and circumstances this complex totemic representation is strict warning of the invincibility and superior force associated with the leader and overall protector of the people and their community. Where applicable, these complex representation is indicative of the different strengths associated with the warriors and front like combatants of that community. This is to say such varied display often also require a study and preliminary findings to understand the real story behind the gallery art on display.

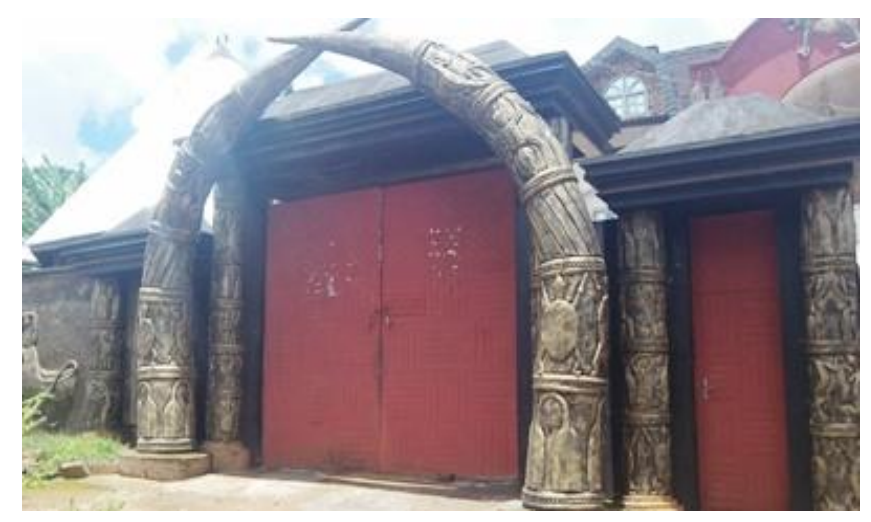

Santa Palace; August 2014

Source: (Donatus F Tangem 2014) 
Apart from showcasing these iconographic symbols at entrances and galleries, Erick Nganjoh of Kungi indicates that it is important to represent same on stools and thrones to further highlight the powers of the Fon. It is thus common to find sculpted lions, elephants and related royal symbols on the thrones and royal stools in the Grassfield. Toh Robert corroborates that sitting on a throne or stool decorated with effigies or sculpted images of lion and elephant is to prefigure the overriding power of the occupant of the stool. If the painting and live images of lion, leopard and the elephant are displayed in and around palaces as royal symbols, then it is not surprising that they are used as motif on stools and thrones. Most Grassfielders have great admiration for the awe that the royal animals inspire. As such it is often employed in greetings of the Fon. In traditional communities, the Fons are referred to as Lion, Leopard and Elephant. The Wimbum of Nkambe refer to the Fon as Nyar buffalo.

On certain occasions the Fon is referred to, in multiple titles such as Elephant, Leopard, Lion and Tiger all at once. Hence to represent those on the stools and thrones of the Fon is a metaphoric imagination that is in tune with accepted practice, belief and culture of the people. It is thus common to see a Fon sitting on a throne with elephant and buffalo motifs with his feet on the coat of a leopard and guarded on each of his sides by huge tusks of the elephant. These insignias only capitalize the immeasurable strengths and supernatural dispositions with which the leader of the community is associated. The entire iconographic symbols that feature on Grassfield thrones and stools are lizards, scorpions, earth spider, chameleon and the tortoise motif among many others. Behind each of these, is great and profound imaginations, beliefs and mythic or mystic accounts linking the motif with royalty and also authenticate its value in the community. In the Grassfield, the scorpion symbolizes the revered authority and extremely dangerous powers of the Fon. Daring a scorpion is risking a deathly string. This is similar to the boa constrictor motif, where the Fon is seen to be harmless but once provoked can emit deadly poison from which its attacker cannot escape. In other words, the earth spider like the tortoise motif is associated not with wild deadly action but rather with the calm wisdom and gentle ways (Ngiti 2013) explains that:

The earth spider is generally viewed among Oku people as a royal emblem symbolizing the wisdom and enlightenment of the Fon. The tortoise on its part is associated both with wisdom and cunningly crafty. Its ability for self-defence by recoiling in its shell and emerging once danger is over symbolize safety and wisdom (P.103).

It is fair to specify that although the Grassfield as a whole adopt various reptiles and animals as royal symbols, there are tiny variations in the details regarding their adoption and use in different Fondoms. It is also very common in the Grassfield to see the use of humans as motifs. The use of either male or female figures is sometimes motivated by love, respect and honour reserved for the person. This is often in recognition of his memorable service to the Fondom. According to (Lantum 2000)

These figures were commemorative and generic renderings of royal ancestors and carved expression to the belief in ancestors as warrantors of social order and property in the Fondom. They also testified to and recorded the dynastic succession. They were carved either during a Fon's reign or to honour his successor (P. 34).

The cultural prescription that obliges successive Fons to sponsor sculptured images of their predecessor is salutary as it shades light on the dating of objects, styles and reigns of kings. This is to affirm that in preliterate era such visual representations made for historical recapitulation. It is propitious to underscore here that the Balis have high respect for the tradition of erecting commemorative statues and monuments representing all deceased Fons. The life size, giant statues lined out with dates of reign at the main entrance to the palace of Bali-Nyonga, represent hard historical data about the Fondom and the period of time each of the Fons reigned.

\section{Life Size Statues of DeCEASEd Fons OF BALI NyONGa}

In the Mankon palace, similar historical data is represented on relief carving portraying the different reigns and dates of Fon Angwafor II's predecessors. Through the plate, snippets of history and characteristic activities predominant during their reigns are clearly recorded. Referring to this style of relief carving, Robert Toh confirms that it is his duty as a people's servant and some sort of community chronicler to represent stories, events and reigns of Fons through carving. He performs this task with passion and derives real fulfilment for the community service he renders to individuals, a people and the general community at large. That sometimes this job comes with accompanying 
Beyond Art, History and Social Discourse: A Study of Folk Art as Indigenous Knowledge System in the Grass Field of Cameroon

financial gains that enable him sustain his family or with traditional decorative rewards that make him distinct in his community, is also admirable and salutary traditional approach for the valorisation of generosity, service and hard work. Therefore traditional schemes abound through which individuals are recognised and rewarded for worthy and selfless services rendered for the preservation of values considered necessary for the sustenance of societal law and order.
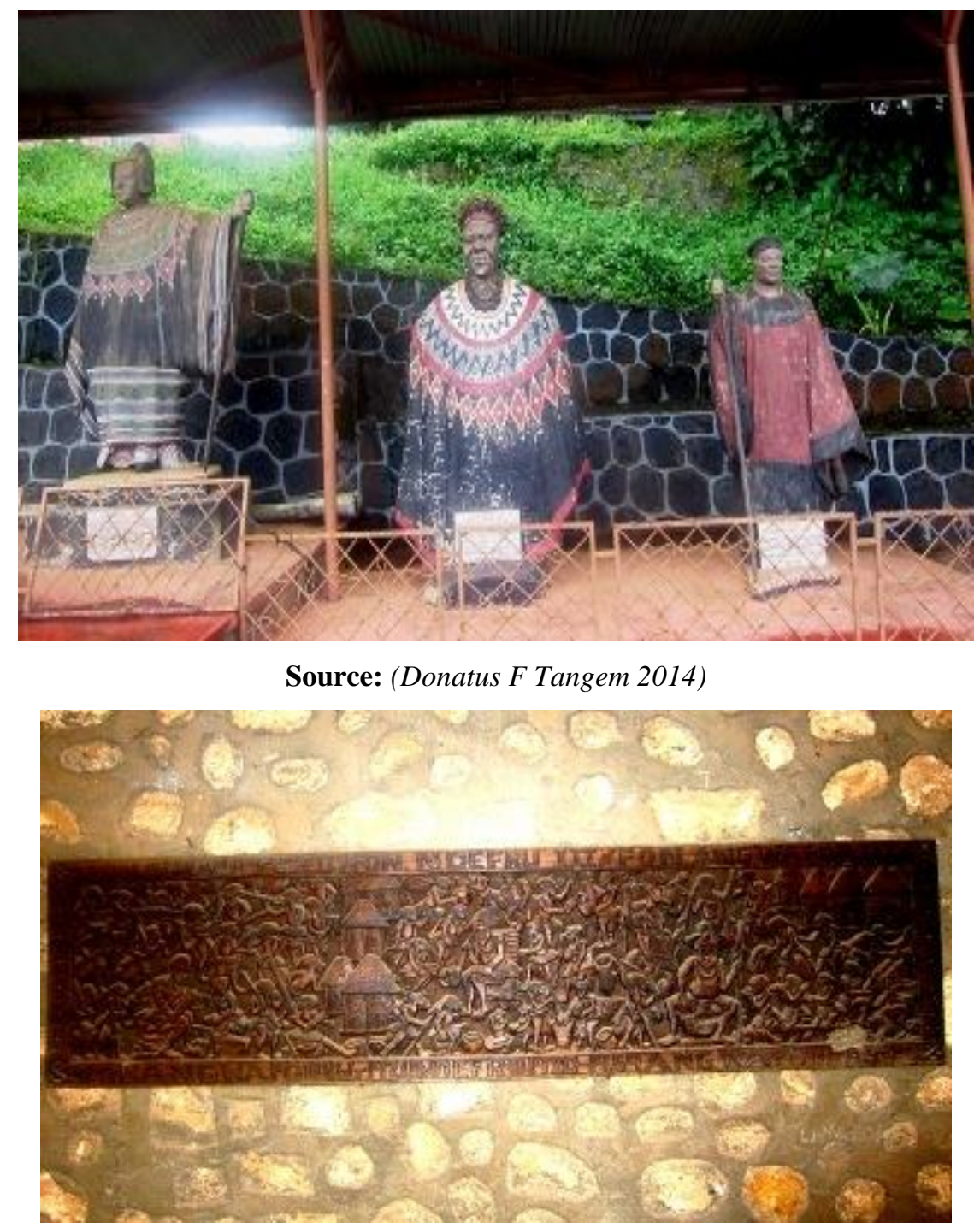

Relief Carvings of Mankon Fons. Mankon Palace, August 2014

Source: (Donatus F Tangem 2014)

As could be deduced from the views of Toh Robert, the job of a community carver was a sacred one. The carver specifies that in doing his job, he is often guided and motivated by supreme spirits. He says he discusses with the wood and simply allows the invisible hand of the community and his ancestors to guide him in bringing out only the truth. The final product, he says is the result of spiritual effort and gratitude goes to his ancestors for accompanying him in the daunting task of documenting and representing communal values and cherished memories.

The Fon of Kungi in Nkambe Central Sub-Division refers to one of the commemorative statues in the palace as "Shey Ntoh" meaning the "palace keeper". He explains that the statue was made in memory of a celebrated community member owing to his relentless struggles to restore peace during heated succession disputes that broke out many years ago and whose efforts resulted in the peaceful resolution and restitution of royal authority. This statue he says, is embedded with such powers that even in the physical absence of the Fon, the statue maintains discipline in the palace. The Fon is able to get updates of every happening that occur during any short or long stay away from the palace. How this is done is the guarded secret of the royal palace of Kungi. What is however no secret is that "Shey 
Ntoh" is constantly sheltered by the peace plant known as "Nkeng". When need be, a leaf of the plant is harvested and used either as injunction or convocation. It is commonly believed in Kungi that, no one ever contravened the orders of "Shey Ntoh". Whenever he dishes out instructions there is no room for disobedience. Even the Fon may not act contrary to the expectations of popular will as incarnated by "Shey Ntoh".

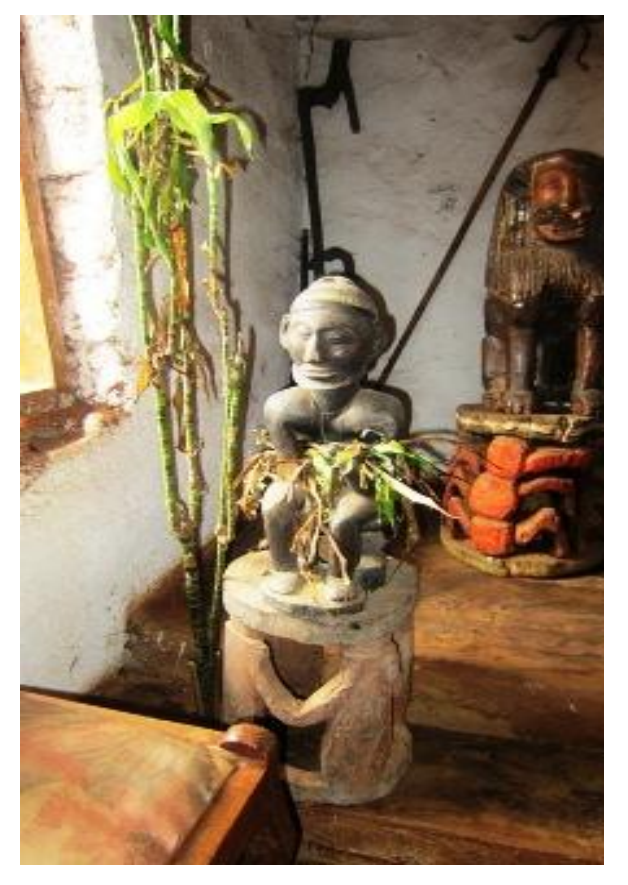

\section{"Shey Ntoh"; Kungi Palace. August 2014}

Source: (Donatus F Tangem 2014)

In the Grassfield as a whole, human beings as motif figure on stools and thrones. The Fon of Nkambe once more points to the importance of a stool or throne supported by five king makers of the Fondom. Accordingly, the stool showcases the unanimity of five king makers whose concerted action and agreement is made manifest through the enthronement of the person who occupies it. Erick Nganjo, a reputable community carver believes that the Fon cannot sit on the throne or such stool to chat with friends and visitors on matters of personal interest In Kungi, like in Mbot, Mankon and Bali-Nyonga palace, there are different thrones, sizes and shapes at the slightly elevated stage where the Fon sits. The design of most Grassfield palaces provides the Fon with an elevated platform from which he overlooks the entire auditorium. From such slightly elevated high ground, he is able to cast an eye of control on the entire hall. Additionally the stage dispositions make provision for different thrones with different implications. To open a discussion or make decisions regarding the welfare of the kingdom, the Fon is expected to sit on the throne that is sustained by either full human or human head motifs. According to Ni John Fru Ndi, the advent of multiparty politics obliged Fons who were politically active to introduce political thrones on which they must sit before venturing political issues. Since African political game makes provision for lies and bias judgment, Grassfield Fons have had to negotiate a safe way by which to evade the truth without risking ancestral punishment. The only way to guarantee safety is to stay away from the royal throne that is impregnated with uncompromising spirits. The role and position of Fons sometimes conflicts with political interest. Since such spirits are uncompromisingly obdurate, refusing to tolerate the slightest signs of action that may comprise communal welfare, the only way to stay safe of ancestral wrath is to keep off the real royal throne when handling issues of personal gains.

The management of Prescraft in Bamenda, requesting anonymity, opines that there are issues about some Fons in the Grassfield who since enthronement have not taken their rightful posture on the royal throne. This is because such Fons are aware of the drastic consequences should they try to tempt ancestral spirits by sitting on the throne in a palace they are occupying illegally. Robert Toh also adds that even as carver, he does not have any right to sit on a stool on which there is human heads. Such stools, he emphasises are not for commoners. 
Beyond Art, History and Social Discourse: A Study of Folk Art as Indigenous Knowledge System in the Grass Field of Cameroon

Inner view of Mankon palace (and Kungi palace (further down). August 2014
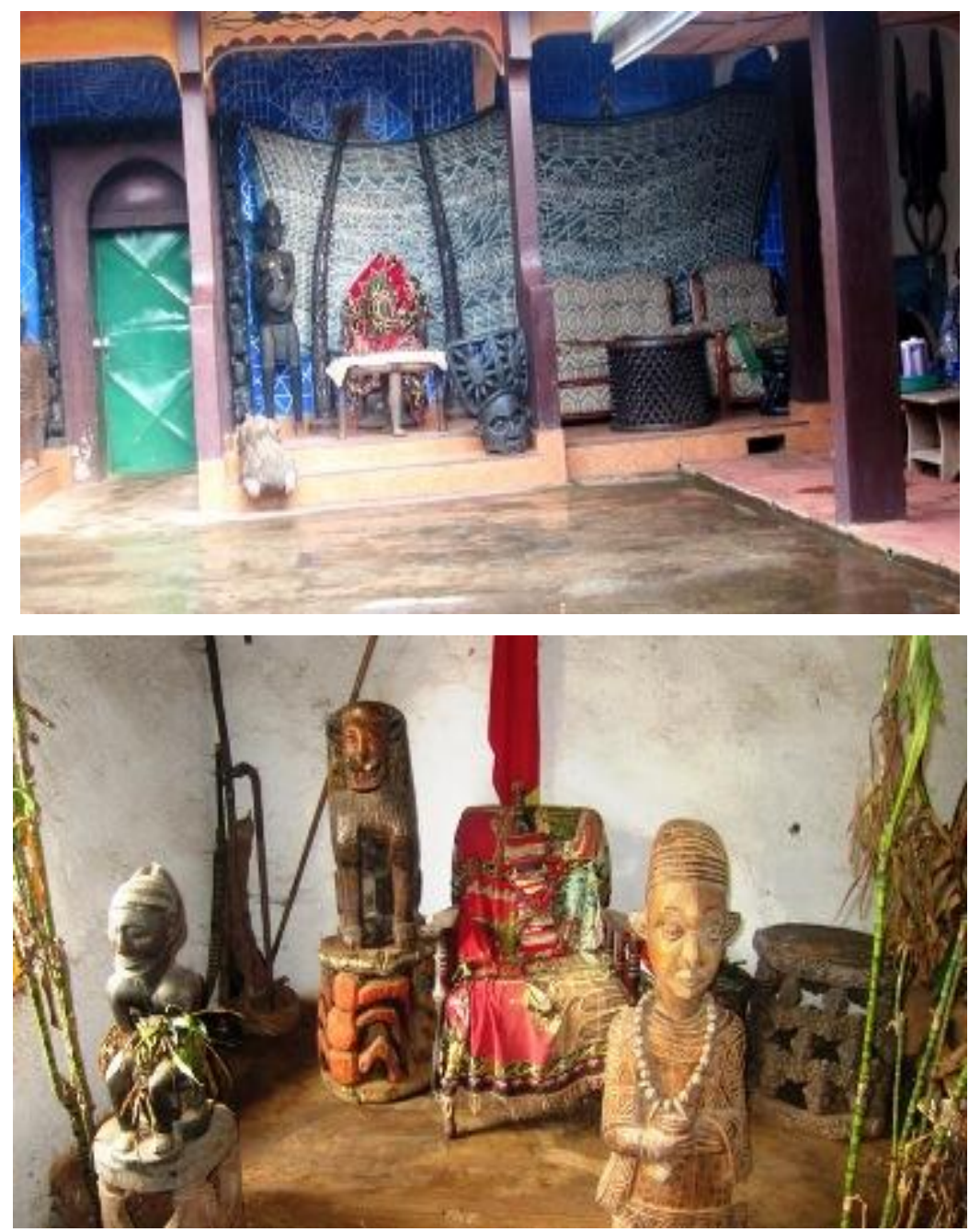

Source: (Donatus F Tangem 2014)

Other serious pretext for the display of folk art in the Grassfield that needs careful study is the phenomenon of secret societies and regulatory bodies. It is common knowledge that every Fondom in the Grassfield is endowed with a hierarchical setting which consists of different sectors, departments and responsibilities. While the Fon is at head, Nwerong, or Ngumba also known as Kwifon is the counter force with which the Fon must collaborate. Other sub units include men, and women's cults such as Nfuh, Njuh, Samba, and other associations that have clearly defined functions. Although all these units have representative sculptures at their door posts and frames, the case of Nfuh is particularly unique. In the Grassfield, the Nfuh is generally thought of as the defence unit. It is the Nfuh and its warriors that fight either in defence of the Fondom or in its bid for expansion. Therefore the door frames of Nfuh house, what (Kropfli 1998:82), refers to as "Law House" is often laced with full human as motif, human heads, female and male respectively. The Fon of Nkambe indicates that by projecting human beings and related motifs, the defence wing of the palace seeks to publish and make public its strength and the extent of its recorded activities. The different human related motifs tell of the outcome of its exploits and accounts of the outcome. Where the human head motifs predominate, Fon Budih III of Kungi suggests that it is an indication of the victims of wars whose heads are captured on door frames. In the warring days, the only proof of strength and triumph over any enemies in battle was the presentation of the heads of slayed warriors from the other camp.

Valiant fighters had to present evidence of great feat in return for upgrading of ranks and the reward with a red feather, farm land or palm bush. In other instances, where warriors throw up arms and surrendered to the supreme force, they were captured and brought home to serve as slaves in the Fondom of their captors. There is recorded evidence of a slave captive who fell in love and had sex 
with a prince in his land of captivity. As supreme punishment for his foolhardiness, the slave was simply beheaded. This story, Erick Nganjo, holds that was effectively captured in a sculpture by his grandfather. The image he remembers was a headless trunk of young man whose lower part, the groin and testicles were highlighted as if to say, his penis was the cause of his tragic death. This image Nganjoh insist is sufficient warning to anyone with a lecherous mind-set. What this means is that crime and punishment is often depicted in Grassfield cultural artefacts in unmistakeable ways and on sculptures that sare not difficult to understand. According to Hunt and Gunther Kress: 1988,

Meaning is always negotiated in a semiotic process, never simply imposed inexorably from above by an omnipotent author through an absolute code. Traditional semiotics like to assume that the relevant meanings are frozen and fixed in the text itself, to be extracted and decoded by the analyst by reference to a coding system that is impersonal and neutral and universal for users of the code.(P.12)

It stands to reason that the sculpted images and the representative symbols follow a strict code and systematic coding order that cannot be mistaken or misunderstood. However, the reality and authentic background of a people's culture is expected to be studied prior to attempts at interpreting the pictorial symbols and images perceived on sculpted platforms used or on display at the palaces or in a gallery that serves both locals, strangers and or visitors in the communities

In the Fondom of Kumbo in Bui division, the female motif on Nfuh doors either meant the exchange of a captured warrior with about ten women or it may mean that women who appeared in battle as spies were captured by the superior warriors from the neighbouring Fondom. In yet other sad cases, after a decimation of the warriors and complete capture of the land, even notables and title-holders could be captured and taken along as practical demonstration of the supremacy of the victorious Fondom. The reward for such high profile victory sometimes was that the warriors took over the wives of their victims. Female motif at the entrance of a Nfuh house was therefore an explanation of any such incident and supreme powers of the warriors anxious to publicize as warning to any contemplative and likely assailant. These explanations are in tandem with the hard evidence in (Leeuwen T Van; 2005) that:

In social semiotics, resources are signifiers, observable actions and objects that have been drawn into the domain of social communication and that have a theoretical semiotic potential constituted by all their past uses and all their potential uses and an actual semiotic potential constituted by those past uses that are known to and considered relevant by the users of the resource, and by such potential uses as might be uncovered by the users on the basis of their specific needs and interests. Such uses take place in a social context, and this context may either have rules or best practices that regulate how specific semiotic resources can be used, or leave the users relatively free in their use of the resource. (P 35)
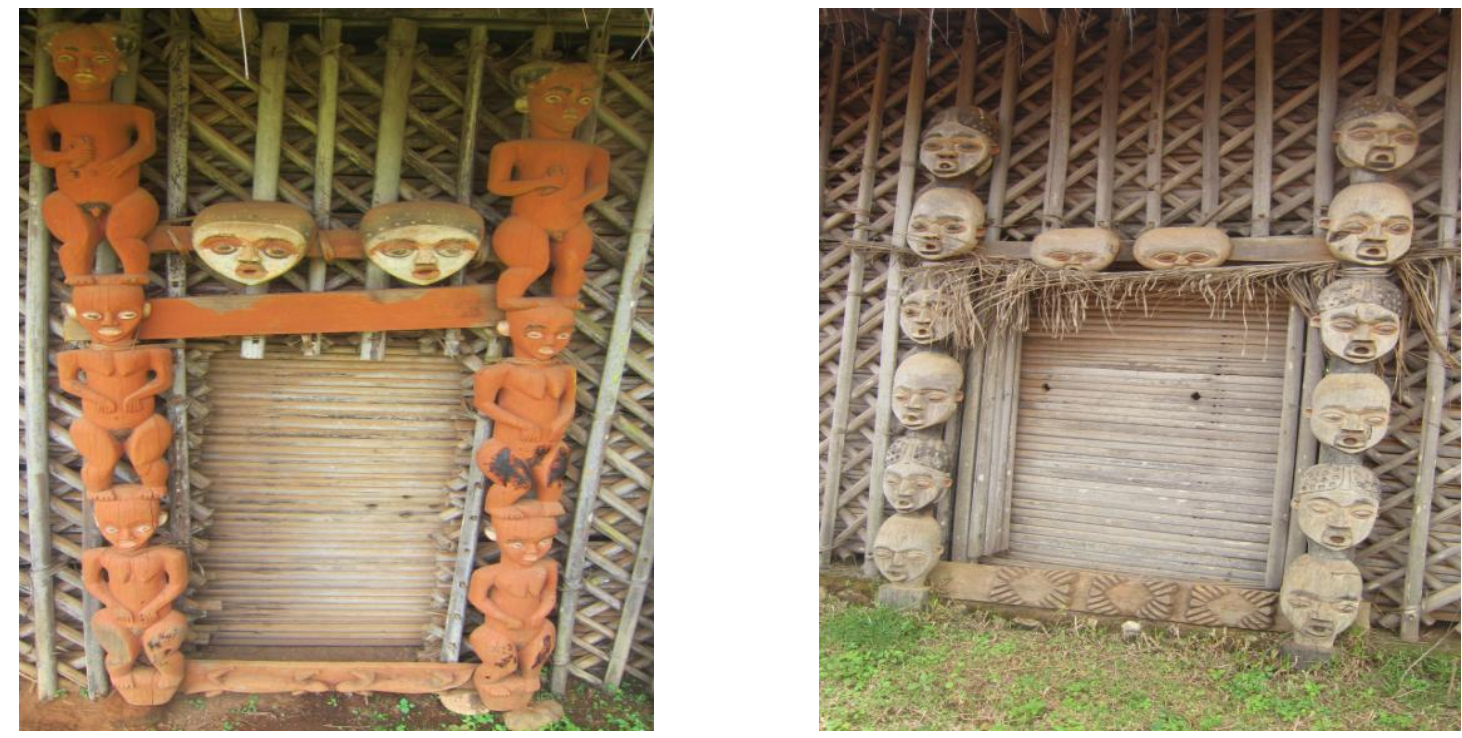

Source: (Donatus F. Tangem 2014) 


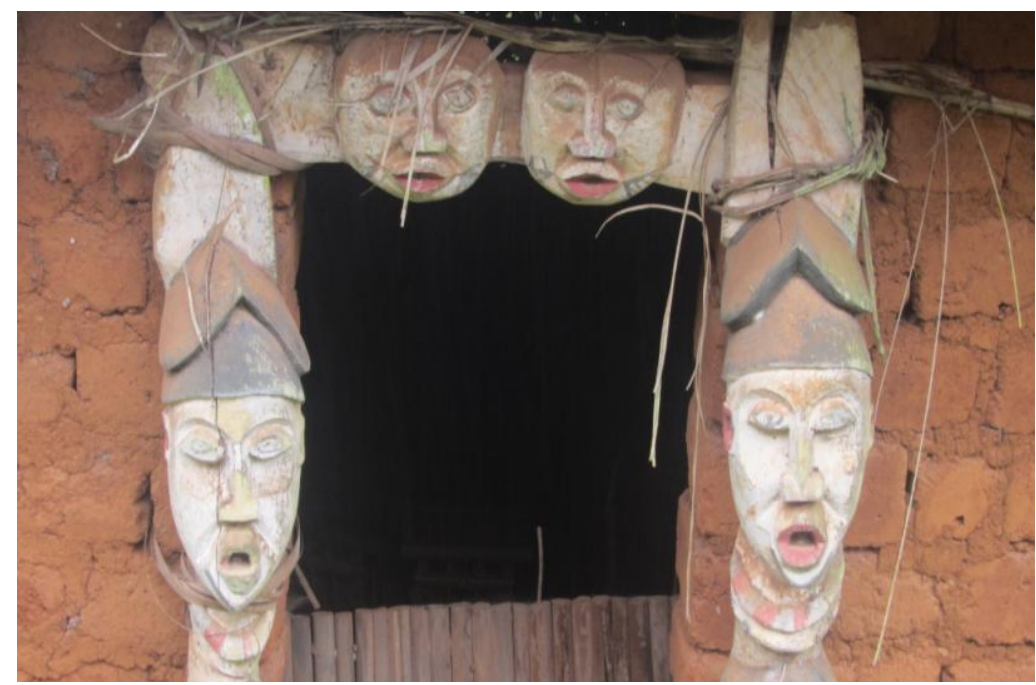

Nfuh house; Kungi palace. August 2014 /

Source: Donatus F. Tangem
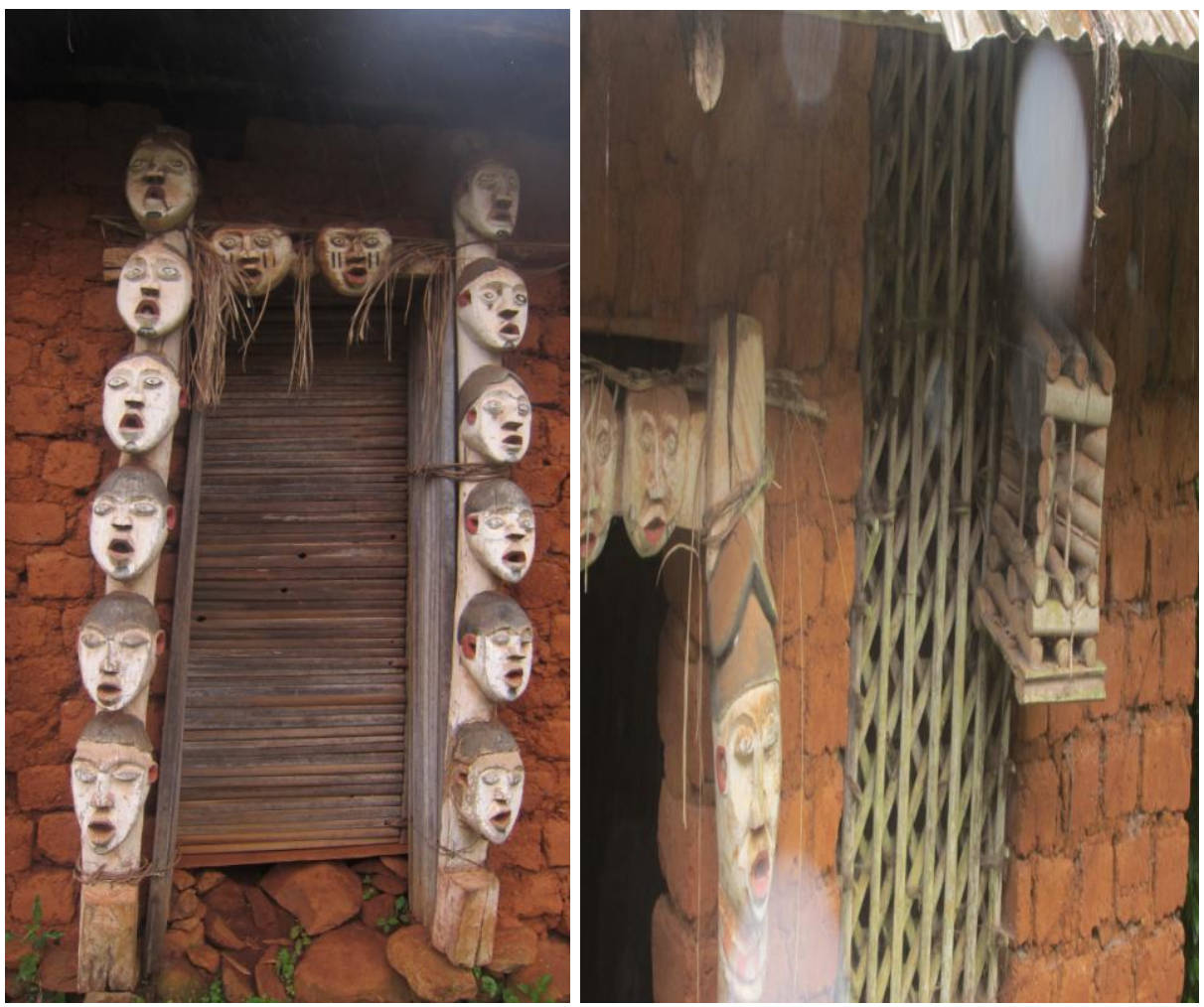

Source: (Donatus F. Tangem 2014)

In yet other cases warriors in young developing dynasties without any war experiences would use animal motif in view of human ones. After all, courageous hunters equally secured promotion and earned red feathers by presenting animals captured during hunting expeditions.

The internal organisation of the Nfuh gives room for promotion and reward based on evidence of loyal service to the Fondom. Within the house, all members have and possess seats, basically stools on which they sit during discussion sessions. In the event of the passing away of a member, his stool is taken out and suspended conspicuously outside the building as announcement or public notification of bereavement. Where applicable, funeral rites are performed and soon after burial, discussions open for a replacement. The ideal setup is usually for the son of the deceased to be initiated. In the event that the deceased has no male child, further procedures are engaged to get the child of either a loyal friend or an extended family member. To say the least, the internal organization of the Nfuh cult 
group takes cognizance of community values, hopes and expectation. Above all, it is believed among Grasslanders that member of Nfuh who engaged in extra marital activities with a member's wife reaped instant results and extreme punishment for the act. In the event of any such misfortune, the Nfuh leader - Ta Tamfuh, chief warrior may commission the community carver to represent the story through sculpted articles that are then posted on the inner walls for future reference.

\section{General Conclusion}

The preceding discourse establishes with irrevocable evidence that folk art in general and especially that of the Grassfield of Cameroon is embedded with deep significance and value. The legitimate wish to improve conditions of existence and also further adherence to dignifying standards are available in all cultures. The phenomenal discriminatory and bias rating of African Arts and cultures by some conservative scholars must give way to the ideals of cultural relativism that appeal for a review of measuring parameters and the appreciation of other cultures for their intrinsic worth. It is in the interest of this accommodative bargain that (Hodge and kress:1988) continue to affirm: "In its terms, everything in a culture can be seen as a form of communication, organised in ways akin to verbal language, to be understood in terms of a common set of fundamental rules or principles",(P1). Therefore, through the agency of social semiology, African, Cameroonian folk music and sculpture make provision for the documentation of events, reigns or period of stewardship and collective memory.. With or without Western influence, African traditional art boast of profound indigenous knowledge system that betray no complexes or shortcomings compared to Western and Westernized information and knowledge generation systems. Paul Jenking's conviction in the preface to (Kropfli 2009), may well qualify as collective apologia on behalf of conservatives and Western scholars with degrading and bias views of African affairs. His personal conviction is that:

Both insiders and outsiders need to be sensitive to the huge but different achievements of which the human spirit has shown itself to be capable everywhere. Closeness to the people of the Western Grass Fields of Cameroon has moved (many) away from seeing African culture as primitive... He also asserts that they are totally different from the prejudiced and discriminatory view of Africa still so widespread in Europe (p. 4).

\section{REFERENCES}

[1] Boon, J. (1972). From Symbolism to Structuralism. New York: Harper and Row Publishers.

[2] Chem-Langhëe, B. and Fanso, V.G. Eds. (1996). Nso and Its Neighbors: Readings in Social-History. Massachusetts: Amherst College.

[3] Chilver, E.M. \& Kaberry, P.M. (1995). Traditional Bamenda: The Pre-colonial History and Ethnography of the Bamenda Grassfields. Buea: Government Printers.

[4] Diop, C.A. (1981). Civilisations ou Barbarie, Paris: Présence Africaine.

[5] Essomba, J.M. (1982). L'Art Traditionnel au Cameroun: Statues et Masques. Austria Suresnes: Jean Dupuch Editions.

[6] Hodge, R. \& Kress, G. (1988), Social Semiotics. New York: Cornell University Press.

[7] Knopfli, H. (1998). Sculpture and Symbolism : Crafts and Technologies : Some Traditional Craftsmen of the Western Grasslands of Cameroon: Part 2 - Woodcarvers and Blacksmiths. Limbe: Presbook Publication.

[8] Knopfli, H. (2002). Living in Style : Crafts and Technologies: Some Traditional Craftsmen and Women of the Western Grasslands of Cameroon. Limbe: Presbyterian Printing Press Limbe.

[9] Lantum, D.N. (2000). Fon Nso 'Sehm Ataar, 1947-1972: Father of Nso Development. Kumbo: Nso History Society Publication.

[10] Leeuwen T V.(2005). Introducing Social Semiotics, U S A and Canada: Rutledge

[11] Loftus, R. (1985). A Visual History of Africa. London: Evans Brothers Limited.

[12] Nkwi P. N. (1989). The German Presence in the Western Grassfields 1891-1913: A German Colonial Account. Leiden: African Studies Centre.

[13] Notue, J. P. and Triaca, B. (2005). Mankon: Arts, Heritage and Culture from the Mankon Kingdom. Milan: COE, 5 Continents Editions.

[14] Nyamndi, B. N. (1988). The Bali Chamba of Cameroon: A Political History. Paris: Editions CAPE.

[15] Titanji, V. et als. (1988), an Introduction to the Study of Bali-Nyonga: A Tribute to His Royal Highness Galega II, Traditional Ruler of Bali-Nyonga from 1940-1985. Yaounde: Stardust Publishers. 


\section{AUTHOR'S BIOGRAPHY}

Donatus Fai Tangem (PhD), is lecturer of Drama/Theatre in the Department of Arts and Archeology, University Of Yaoundé1. He is also a community development consultant and environmentalist interested in workshops /training on human rights, democracy and governance. One of his ground breaking projects is the British High commission sponsored venture code-named "The Cameroon Climate Change Road Show" an initiative that combined theatre performances with practical tree planting exercises. In this, Donatus wrote and directed a play entitled "Combating the Monster, Combating Change», a play which through song, dance and dialogue radiate educative discourse on major concepts, theories and best practices in the struggle against climate change.

Citation: Donatus, Fai Tangem. "Beyond Art, History And Social Discourse: A Study of Folk Art as Indigenous Knowledge System in the Grass Field of Cameroon." International Journal of Humanities Social Sciences and Education (IJHSSE), vol 4, no. 9, 2017, pp. 58-74. doi:http://dx.doi.org/10.20431/23490381.0409009 .

Copyright: (c) 2017 Authors. This is an open-access article distributed under the terms of the Creative Commons Attribution License, which permits unrestricted use, distribution, and reproduction in any medium, provided the original author and source are credited. 